Article

\title{
Toward an Integrated Model of Topical, Spatial, and Temporal Scales of Research Inquiry in Park Visitor Use Management
}

\author{
Elizabeth E. Perry ${ }^{1, * \mathbb{D}}$, Jennifer M. Thomsen ${ }^{2}$, Ashley L. D'Antonio ${ }^{3}$, Wayde C. Morse ${ }^{4}$, \\ Nathan P. Reigner ${ }^{5}$, Yu-Fai Leung ${ }^{6}{ }^{\oplus}$, Jeremy Wimpey ${ }^{7}$ and B. Derrick Taff $\left.{ }^{5}{ }^{(}\right)$ \\ 1 Department of Community Sustainability, Michigan State University, East Lansing, MI 48824, USA \\ 2 Department of Society and Conservation, University of Montana, Missoula, MT 59812, USA; \\ jennifer.thomsen@umontana.edu \\ 3 Department of Forest Ecosystems and Society, Oregon State University, Corvallis, OR 97331, USA; \\ Ashley.D'Antonio@oregonstate.edu \\ 4 School of Forestry and Wildlife Sciences, Auburn University, Auburn, AL 36849, USA; morsewc@auburn.edu \\ 5 Department of Recreation, Park, and Tourism Management, Pennsylvania State University, \\ State College, PA 16801, USA; npr5097@psu.edu (N.P.R.); bdt3@psu.edu (B.D.T.) \\ 6 Department of Parks, Recreation and Tourism Management and Center for Geospatial Analytics, \\ North Carolina State University, Raleigh, NC 27695, USA; leung@ncsu.edu \\ 7 Applied Trails Research, LLC, State College, PA 16803, USA; jeremyw@appliedtrailsresearch.com \\ * Correspondence: eeperry@msu.edu
}

Received: 1 July 2020; Accepted: 29 July 2020; Published: 31 July 2020

\begin{abstract}
Parks and protected areas (PPAs) are facing complex, transboundary, social, and ecological pressures, including those related to visitor use. Effective visitor use management (VUM) in PPAs requires interdisciplinary thinking across multiple spatial and temporal scales. Yet, the majority of this VUM research is short-term and occurs at relatively discrete spatial scales. A few existing frameworks and conceptual models used in VUM encourage thinking across scales. No single, interdisciplinary conceptual model exists, however, despite longstanding recognition of the need for one. This need was highlighted as a research priority by PPA and VUM subject area experts from across the U.S. at a workshop at Clemson University in 2018. This manuscript draws from the discussions at that workshop and addresses this recognized need. We propose and describe a single multi-scalar conceptual model that integrates topical areas in PPA VUM. Thoughtful, multi-scalar research that transcends disciplines is essential to address contemporary issues across VUM topics. The proposed model and the subsequent discussion are meant to serve as a catalyst for VUM researchers to begin considering both spatial and temporal scales in their PPA-based inquiries.
\end{abstract}

Keywords: protected area; tourism; conservation social science; multi-scalar; scaling up; social-ecological systems; systems management; visitor use management; spatiotemporal; recreation

\section{Introduction}

Parks and protected areas (PPAs) are increasingly facing issues influenced by forces beyond their boundaries. To sustainably address complex PPA-based issues, visitor use management (VUM) managers and researchers must consider dimensions of both spatial and temporal scales (henceforth inclusively termed "scales"). VUM issues center on sustainable recreation [1] and are often a top challenge faced by PPA managers. These issues may seem discrete, bound by space (a particular location) and time (a particular event), but many influences on them transcend the PPA context and warrant systems-level approaches (e.g., climate change, demographic shifts, funding patterns). Despite 
the need to consider multiple scales of inquiry, VUM research has mostly occurred on local, short-term scales, as PPA-specific and managerially-timed issues drive unit-level analyses [2] (see Table 1 for definitions of VUM and scales as they apply in this context). This is often done without the explicit recognition of other scales of analysis or cross-scale interactions that might influence the results of these studies. This limited focus has constrained the PPA VUM (henceforth termed "VUM," with the PPA context implicit) discipline's ability to grow theoretically and hindered our ability to inform managers to address larger issues. Embracing interdisciplinary tools, including examining VUM issues both at scales relevant to social-ecological systems (SES) and across disciplinary lenses, is required to incorporate multi-scalar, systems-level understanding, and advance the VUM discipline.

Table 1. Terms and definitions as they are applied in the context of this manuscript.

\begin{tabular}{cc}
\hline Term & Definition \\
\hline Visitor Use Management & $\begin{array}{c}\text { "Proactive and adaptive process for managing characteristics of } \\
\text { visitor use and the natural and managerial setting using a variety of } \\
\text { strategies and tools to achieve and maintain desired resource } \\
\text { conditions and visitor experiences." [1] }\end{array}$ \\
\hline Scale & $\begin{array}{r}\text { A range of levels that can represent the size or extent of an event, } \\
\text { process, and/or phenomenon. }\end{array}$ \\
Spatial Scale & $\begin{array}{c}\text { The extent of a process or event; the area under which a } \\
\text { phenomenon is analyzed or summarized. }\end{array}$ \\
It is important to note that we are using scale in a geographic sense \\
and not in reference to cartography (where a "small scale" map \\
shows a large geographic area). As such, we are using terms \\
common in geography and ecology, and using small, medium, and \\
large as general terms to describe spatial scale. Specific examples are \\
provided in Tables 2-4.
\end{tabular}


Table 2. Descriptions of aspects and associated spatial and temporal scales of visitor use management research in parks and protected areas (PPAs).

\begin{tabular}{|c|c|c|c|c|c|c|c|}
\hline \multirow{2}{*}{ Dimension } & \multirow{2}{*}{ Aspect and Description } & \multicolumn{3}{|c|}{ Description of Spatial Scale } & \multicolumn{3}{|c|}{ Description of Temporal Scale } \\
\hline & & Small & Medium & Large & Short & Medium & Long \\
\hline \multirow{3}{*}{ Managerial } & $\begin{array}{l}\text { Adaptive Governance: Flexible } \\
\text { approaches to management } \\
\text { acknowledging complexity }\end{array}$ & PPA manager & $\begin{array}{l}\text { Regional adaptive } \\
\text { management } \\
\text { strategies }\end{array}$ & $\begin{array}{l}\text { Social-ecological } \\
\text { systems-based } \\
\text { management }\end{array}$ & Informal connecting & Scenario planning & $\begin{array}{l}\text { Agency culture } \\
\text { changes }\end{array}$ \\
\hline & $\begin{array}{c}\text { Economic: } \\
\text { Economic impact and demand } \\
\text { studies }\end{array}$ & PPA & PPA system & National level & $\begin{array}{l}\text { Singular, } \\
\text { cross-sectional study }\end{array}$ & $\begin{array}{l}\text { 5-year cyclical trend } \\
\text { development }\end{array}$ & $\begin{array}{l}\text { 10-20 year systematic } \\
\text { national study }\end{array}$ \\
\hline & $\begin{array}{l}\text { Organizational Learning: } \\
\text { Growth with acquired experience }\end{array}$ & PPA staff trainings & PPA & $\begin{array}{l}\text { Regional or national } \\
\text { network of PPAs }\end{array}$ & $\begin{array}{l}\text { Experience and } \\
\text { dialogue }\end{array}$ & $\begin{array}{l}\text { Shared understanding } \\
\text { and engagement }\end{array}$ & $\begin{array}{l}\text { Institutionalizing; } \\
\text { policy }\end{array}$ \\
\hline \multirow{3}{*}{ Resource } & $\begin{array}{l}\text { Abiotic: } \\
\text { All non-living objects and elements } \\
\text { in an ecosystem }\end{array}$ & Local/site-level & $\begin{array}{l}\text { PPA-level physical } \\
\text { landscape and } \\
\text { geodiversity }\end{array}$ & $\begin{array}{l}\text { Regional and } \\
\text { continental scale }\end{array}$ & $\begin{array}{l}\text { Diurnal or } \\
\text { incremental changes; } \\
\text { minutes to days }\end{array}$ & $\begin{array}{l}\text { Recurring seasonal } \\
\text { dynamics; years to } \\
\text { naturally occurring } \\
\text { multi-year cycles }\end{array}$ & $\begin{array}{c}\text { Geologic-scale } \\
\text { changes in landscape } \\
\text { or physical processes; } \\
\text { hundreds to billions of } \\
\text { years }\end{array}$ \\
\hline & $\begin{array}{l}\text { Biotic: } \\
\text { All living organisms in an ecosystem, } \\
\text { including PPA visitors }\end{array}$ & Local/site-level & Regional & Landscape or biome & $\begin{array}{l}\text { Biological processes } \\
\text { occurring over hours } \\
\text { to weeks }\end{array}$ & $\begin{array}{l}\text { Biological processes } \\
\text { occurring over months } \\
\text { to years }\end{array}$ & $\begin{array}{l}\text { Biological processes } \\
\text { occurring over } \\
\text { decades or longer }\end{array}$ \\
\hline & $\begin{array}{l}\text { Infrastructure: } \\
\text { PPA physical infrastructure to } \\
\text { accommodate administration and } \\
\text { visitor uses }\end{array}$ & Individual features & $\begin{array}{l}\text { Clusters of features } \\
\text { and linear features }\end{array}$ & $\begin{array}{l}\text { Transportation and } \\
\text { recreation } \\
\text { infrastructure across } \\
\text { PPAs }\end{array}$ & $\begin{array}{l}\text { Infrastructure for a } \\
\text { single event or } \\
\text { temporary } \\
\text { infrastructure } \\
\text { installation }\end{array}$ & $\begin{array}{l}\text { Use of infrastructure } \\
\text { across weeks or } \\
\text { months or seasonal } \\
\text { closure/opening of } \\
\text { infrastructure }\end{array}$ & $\begin{array}{l}\text { Proactive, long-term } \\
\text { planning of } \\
\text { infrastructure needs, } \\
\text { informed by past and } \\
\text { forecasted uses }\end{array}$ \\
\hline \multirow{3}{*}{ Social } & $\begin{array}{l}\text { Health and Well-being: } \\
\text { Physical and mental health and } \\
\text { well-being outcomes associated with } \\
\text { recreation in a PPA }\end{array}$ & $\begin{array}{l}\text { Health outcomes } \\
\text { for an individual } \\
\text { from a specific } \\
\text { setting or } \\
\text { PPA-based activity }\end{array}$ & $\begin{array}{l}\text { Health outcomes for a } \\
\text { demographic from } \\
\text { PPA-based activities }\end{array}$ & $\begin{array}{l}\text { Health outcomes from } \\
\text { broader outdoor } \\
\text { recreation in all PPAs }\end{array}$ & $\begin{array}{l}\text { Health outcomes from } \\
\text { a singular PPA visit or } \\
\text { activity }\end{array}$ & $\begin{array}{l}\text { Health outcomes from } \\
\text { repeat PPA visits or } \\
\text { activities }\end{array}$ & $\begin{array}{l}\text { Health outcomes over } \\
\text { a period of life or a } \\
\text { lifetime from PPA } \\
\text { visits and activities }\end{array}$ \\
\hline & $\begin{array}{l}\text { Experiential: } \\
\text { Socio-psychologic processes and } \\
\text { products from PPA engagements }\end{array}$ & $\begin{array}{l}\text { An individual's } \\
\text { experience }\end{array}$ & $\begin{array}{l}\text { Experiences available } \\
\text { within a PPA }\end{array}$ & $\begin{array}{l}\text { Experiences available } \\
\text { across PPA systems }\end{array}$ & $\begin{array}{l}\text { Experiences during } \\
\text { active engagement }\end{array}$ & $\begin{array}{l}\text { Experience of a } \\
\text { visit-cycle }^{1}\end{array}$ & $\begin{array}{l}\text { Accumulated and } \\
\text { expected } \\
\text { experiences/antici- } \\
\text { pations }\end{array}$ \\
\hline & $\begin{array}{c}\text { Cultural: } \\
\text { Valuations of human involvements } \\
\text { on the landscape incorporated into } \\
\text { PPAs }\end{array}$ & $\begin{array}{l}\text { PPAs recognizing } \\
\text { particular events, } \\
\text { contributions, or } \\
\text { populations }\end{array}$ & $\begin{array}{l}\text { PPAs incorporating } \\
\text { cultural and heritage } \\
\text { landscapes }\end{array}$ & $\begin{array}{l}\text { PPAs allowing for } \\
\text { human habitation and } \\
\text { traditional uses }\end{array}$ & $\begin{array}{l}\text { Recognizing a } \\
\text { singular event }\end{array}$ & $\begin{array}{c}\text { Recognizing } \\
\text { events/traditions } \\
\text { associated with a } \\
\text { particular time/theme }\end{array}$ & $\begin{array}{l}\text { Recognizing a } \\
\text { persistent and } \\
\text { ongoing } \\
\text { society/culture }\end{array}$ \\
\hline
\end{tabular}

${ }^{1}$ Visit-cycle stages: conception, planning/anticipation, travel to, visit, travel from, and reflection. 
Table 3. Representative examples of different spatial scales of visitor use management research in parks and protected areas (PPAs).

\begin{tabular}{|c|c|c|c|c|}
\hline \multirow{2}{*}{ Dimension } & \multirow{2}{*}{ Aspect } & \multicolumn{3}{|c|}{ Spatial Scale } \\
\hline & & Small & Medium & Large \\
\hline \multirow{3}{*}{ Managerial } & $\begin{array}{l}\text { Adaptive } \\
\text { governance }\end{array}$ & $\begin{array}{l}\text { Encourage a unit-level culture of employee } \\
\text { agency and autonomy to empower individuals } \\
\text { to reach out to a variety of partners and } \\
\text { potential audiences rather than having a } \\
\text { prescribed list of contacts }\end{array}$ & $\begin{array}{l}\text { Institute regional learning networks to try } \\
\text { different engagement approaches across a suite } \\
\text { of units, sharing about the usefulness of } \\
\text { approaches for particular types of units and } \\
\text { audiences, as well as what supports are needed }\end{array}$ & $\begin{array}{c}\text { Recognize encouraging "visitor diversity" across } \\
\text { whole systems is not monolithic and requires a } \\
\text { mindful approach to summarizing people's ties to } \\
\text { individual PPAs, themes, and resources at larger } \\
\text { levels }\end{array}$ \\
\hline & Economics & $\begin{array}{l}\text { At a local PPA: Estimate demand studies to } \\
\text { find value of activity and local community } \\
\text { impact of tourism }\end{array}$ & $\begin{array}{l}\text { State-level, regional system: Regional } \\
\text { economic impact assessments, also by federal } \\
\text { or state agency, independently }\end{array}$ & $\begin{array}{l}\text { Regionwide assessments (District } 8 \text {, the south, etc.) } \\
\text { up to national; can identify trends across region }\end{array}$ \\
\hline & $\begin{array}{l}\text { Organizational } \\
\text { Learning }\end{array}$ & $\begin{array}{l}\text { Individual employees attend a training or } \\
\text { workshop and are exposed to new strategies } \\
\text { and knowledge to assist in their jobs at their } \\
\text { respective units }\end{array}$ & $\begin{array}{l}\text { A PPA assesses their organizational context } \\
\text { and environment to implement new trainings } \\
\text { and improve capacity for the staff to address } \\
\text { specific challenges faced }\end{array}$ & $\begin{array}{l}\text { A system of PPAs, like the U.S. Forest Service or } \\
\text { U.S. National Park Service, implementing a new } \\
\text { initiative for planning and managing multi-use } \\
\text { trails }\end{array}$ \\
\hline \multirow{3}{*}{ Resource } & Abiotic & $\begin{array}{l}\text { Measuring accelerated weathering of a } \\
\text { geological feature caused by visitor traffic and } \\
\text { touching of the feature }\end{array}$ & $\begin{array}{l}\text { Assessing soil loss from a system of trails in a } \\
\text { PPA }\end{array}$ & $\begin{array}{l}\text { Estimating potential loss of geodiversity based on } \\
\text { visitor use patterns and associated geological } \\
\text { heritage on large landscapes }\end{array}$ \\
\hline & Biotic & $\begin{array}{l}\text { Measuring impacts to localized ecosystem (e.g., } \\
\text { biotic community) in a single PPA such as an } \\
\text { individual lake or stream, or single trail } \\
\text { corridor }\end{array}$ & $\begin{array}{l}\text { Measuring impacts at the scale of an entire } \\
\text { PPA, such as a study that examines habitat } \\
\text { fragmentation across a National Forest unit or } \\
\text { multiple agency lands }\end{array}$ & $\begin{array}{l}\text { Exploring the connectivity of PPAs in a mosaic of } \\
\text { landscapes, such as the Yellowstone to Yukon } \\
\text { project }\end{array}$ \\
\hline & Infrastructure & $\begin{array}{l}\text { Individual infrastructure items related to } \\
\text { protection, transportation, and recreation } \\
\text { within a PPA, such as segments of road/trail, } \\
\text { destination features and individual campsites }\end{array}$ & $\begin{array}{l}\text { Local and unit-based systems of infrastructure } \\
\text { related to resource protection, transportation } \\
\text { and recreation, such as the trail system, road } \\
\text { system, campground (multiple sites), or PPA } \\
\text { level }\end{array}$ & $\begin{array}{l}\text { Macro-Global Scale: Connected systems of } \\
\text { infrastructure related to resource protection, } \\
\text { transportation, and recreation at the continental to } \\
\text { global scale, such as PPA-associated regional } \\
\text { transportation networks and long-distance trails }\end{array}$ \\
\hline \multirow{3}{*}{ Social } & $\begin{array}{l}\text { Health and } \\
\text { Well-being }\end{array}$ & $\begin{array}{l}\text { Tracking an individual's physical and mental } \\
\text { health before and after mountain biking at } \\
\text { Lolo National Forest }\end{array}$ & $\begin{array}{l}\text { PPA network (e.g., Rocky Mountain National } \\
\text { Park, Arapaho National Forest) and } \\
\text { regional-level (e.g., county) health indicators } \\
\text { (e.g., NIH - PROMIS Scales) }\end{array}$ & $\begin{array}{l}\text { World Health Org.-Census-level health data (e.g., } \\
\text { life expectancy, chronic disease) paired with } \\
\text { Global Vegetation layers and quantified with PPA } \\
\text { and outdoor recreation data }\end{array}$ \\
\hline & Experiential & $\begin{array}{l}\text { Understanding individual experiences as they } \\
\text { relate to motivations, benefits, and satisfaction }\end{array}$ & $\begin{array}{l}\text { Managing for collective experience quality at } \\
\text { sites or within units as it relates to crowding, } \\
\text { conflict, carrying capacity, etc. }\end{array}$ & $\begin{array}{l}\text { Managing for comprehensive diversity of } \\
\text { experiences available among sites and units as } \\
\text { they aggregate to regional, national, and global } \\
\text { PPA systems }\end{array}$ \\
\hline & Cultural & $\begin{array}{l}\text { Site-level descriptions of the hunter and } \\
\text { companions' experience of subsistence use at } \\
\text { Wrangell St. Elias National Park and Preserve }\end{array}$ & $\begin{array}{l}\text { Supporting Alaskan communities and } \\
\text { continuing the Alaskan way of life }\end{array}$ & $\begin{array}{l}\text { Maintain opportunities for the economic viability } \\
\text { of communities in the global north }\end{array}$ \\
\hline
\end{tabular}


Table 4. Representative examples of different temporal scales of visitor use management research in parks and protected areas (PPAs).

\begin{tabular}{|c|c|c|c|c|}
\hline \multirow{2}{*}{ Dimension } & \multirow{2}{*}{ Aspect } & \multicolumn{3}{|c|}{ Temporal Scale } \\
\hline & & Short & Medium & Long \\
\hline \multirow{3}{*}{ Managerial } & $\begin{array}{l}\text { Adaptive } \\
\text { Governance }\end{array}$ & $\begin{array}{l}\text { Individual employees attend a variety of } \\
\text { community events and create one-time in-park } \\
\text { engagement events to welcome many audiences }\end{array}$ & $\begin{array}{l}\text { Multiple PPAs and partners in the region } \\
\text { convene regularly to assess strategies and } \\
\text { co-create a suite of potential engagements }\end{array}$ & $\begin{array}{l}\text { Collaboration is embedded into organizational } \\
\text { cultures so that engagement strategies are diverse } \\
\text { and complementary across whole regions, as are } \\
\text { approaches to testing new strategies }\end{array}$ \\
\hline & Economics & $\begin{array}{l}\text { Cross-sectional one-off recreation demand and } \\
\text { impact study. Most are done this way }\end{array}$ & $\begin{array}{l}\text { Every } 5 \text { years, a new SCORP }{ }^{1} \text { is done. 10-year } \\
\text { forest plan. Agency or grant requirements } \\
\text { drive these. Industry may do these by activity }\end{array}$ & $\begin{array}{l}\text { Federal level data collection that is part of } \\
\text { regulatory requirements }\end{array}$ \\
\hline & $\begin{array}{l}\text { Organizational } \\
\text { Learning }\end{array}$ & $\begin{array}{l}\text { Individual employees and PPAs have dialogue } \\
\text { about how climate change is impacting their unit } \\
\text { and how it should be interpreted to visitors }\end{array}$ & $\begin{array}{l}\text { PPAs create and implement strategies to } \\
\text { mitigate climate change and coordinate with } \\
\text { other units to consistently message to visitors } \\
\text { and manage resources }\end{array}$ & $\begin{array}{c}\text { A system of PPAs (e.g., U.S. Forest Service) shifts } \\
\text { their resources management and staff training } \\
\text { from suppressing fires to actively managing fires } \\
\text { as a systems component }\end{array}$ \\
\hline \multirow{3}{*}{ Resource } & Abiotic & $\begin{array}{l}\text { Measurement of physical alteration of } \\
\text { underground geological features in a PPA before } \\
\text { and after a holiday break }\end{array}$ & $\begin{array}{l}\text { Repeated assessments of trail erosion, or } \\
\text { monitoring of glacier retreat at popular tourist } \\
\text { site, over multiple years }\end{array}$ & $\begin{array}{l}\text { Assessment of visitor-associated change of a sand } \\
\text { dune system over a long period of time, partly } \\
\text { employing historic photos and records. }\end{array}$ \\
\hline & Biotic & $\begin{array}{l}\text { Individual study or research project that } \\
\text { examines a biological phenomenon, such as the } \\
\text { level of impact and extent of social trails, over a } \\
\text { single season, year, or point in time }\end{array}$ & $\begin{array}{l}\text { Study/studies examining the same biological } \\
\text { phenomenon across two or more points in time } \\
\text { in the same location. For example, trampling } \\
\text { studies that examine the recovery of vegetation } \\
\text { from disturbance over } 2 \text { years and then } \\
\text { conducting repeat measures } 10 \text { years later }\end{array}$ & $\begin{array}{l}\text { Long-term research projects, akin to the Long Term } \\
\text { Ecological Research Network, that examine the } \\
\text { same biological phenomenon in the same location } \\
\text { across decades or longer. For example, monitoring } \\
\text { ecological impacts yearly, in the same manner that } \\
\text { many PPAs measure visitor use on a yearly basis }\end{array}$ \\
\hline & Infrastructure & $\begin{array}{l}\text { Use pattern or impact assessment related to } \\
\text { infrastructure (trails, roads, campsites, etc.) at an } \\
\text { hourly or daily scale }\end{array}$ & $\begin{array}{l}\text { Use pattern or impact assessment related to } \\
\text { infrastructure (trails, roads, campsites, etc.) at } \\
\text { a weekly, monthly or season-long scale }\end{array}$ & $\begin{array}{l}\text { Use pattern or impact assessment related to } \\
\text { infrastructure (trails, roads, campsites, etc.) } \\
\text { examining trends or long-term impacts of years to } \\
\text { decades. (Life cycle studies of transportation and } \\
\text { trails) }\end{array}$ \\
\hline \multirow{3}{*}{ Social } & Health & $\begin{array}{l}\text { Tracking heart rate and blood pressure of an } \\
\text { individual before and after they do a single hike } \\
\text { on a Prescription Trail }\end{array}$ & $\begin{array}{l}\text { Tracking mental health of a group of veterans } \\
\text { after a 6-month period of time in a wilderness } \\
\text { setting }\end{array}$ & $\begin{array}{l}\text { Tracking the cardiovascular health of an individual } \\
\text { over several decades with regular visitation and } \\
\text { activity in PPAs }\end{array}$ \\
\hline & Experiential & $\begin{array}{l}\text { Focus on experiential processes and outcomes } \\
\text { during recreational activities while on-site or } \\
\text { during a discrete engagement }\end{array}$ & $\begin{array}{c}\text { Embedding discrete recreational experiences } \\
\text { within frameworks that incorporate } \\
\text { preparatory learning/anticipation and } \\
\text { post-experience reflection/elaboration }\end{array}$ & $\begin{array}{l}\text { Understanding the development, change, and } \\
\text { impact of recreational experiences through life, } \\
\text { focusing on cumulative (rather than discrete) } \\
\text { interactions with PPAs }\end{array}$ \\
\hline & Cultural & $\begin{array}{c}\text { In-group bonding among hunting party } \\
\text { members and connections between hunters, } \\
\text { National Park and Preserve, and community } \\
\text { members }\end{array}$ & $\begin{array}{l}\text { Intergeneration transmission of cultural } \\
\text { practices and identities }\end{array}$ & $\begin{array}{l}\text { Maintenance of ways of life (e.g., seasonal rhythms, } \\
\text { food ways, etc.) that span centuries into prehistory }\end{array}$ \\
\hline
\end{tabular}

${ }^{1}$ SCORP $=$ Statewide Comprehensive Outdoor Recreation Plan. 


\section{Supporting Models and Frameworks}

\subsection{Social-Ecological Systems Thinking}

While social and ecological systems are independently complex, interactions across SES tend to compound complexity [3]. Each system encompasses diverse and interrelated components [4]. Complex systems may form nested hierarchies with emergent properties from lower-level interactions, resulting in higher-level patterns influencing subsequent interactions [5].

Theories such as Hierarchy Theory have aided in simplifying complex SES for greater understanding [6-8]. For example, the multi-scalar analysis of "enveloping" necessitates considering the scale: 1) of focus, 2) above (i.e., the context), and 3) below (i.e., the mechanism) [6,9]. Systems thinking can bridge the social and ecological sciences [3]. Researchers are currently exploring this thinking and related application of scale theory to VUM. VUM is valued and researched at multiple scales (e.g., trail, forest, national forest system), but scale selection is ultimately a human-derived choice rather than an inherent component of SES [6]. McCool and Kline (2020) highlight how traditional recreation models, using linear systems, have failed to anticipate impacts from larger SES [10]. They suggest a VUM paradigm shift to a systems approach incorporating interactions within broader SES contexts [10].

VUM connections within SES are also explored by Morse et al. (2020), who apply "enveloping" from Hierarchy Theory to propose a framework focused on SES outcomes from recreation on individual, societal, local, and ecosystem scales [11]. A parallel social science concept of methodological bracketing from Structuration Theory was integrated for framing-linked SES [12,13]. Morse et al. (2009) detailed the utility of applying spatial analyses common in natural resource management to VUM and identified challenges including incongruent boundaries, mismatched scales for different resources, and the need for multi-scalar analyses. They also applied Hierarchy Theory and "enveloping" to two common VUM frameworks, the Recreation Opportunity Spectrum (ROS) and Limits of Acceptable Change, to better understand trade-offs related to SES management. They concluded that multi-scalar analyses are compatible with methodologies associated with these frameworks, given the ubiquitous use of mapping technologies and sensitivity to scale-specific contexts [14]. However, multi-scalar approaches are rarely used in VUM and many studies are focused on relatively narrow scales.

\subsection{Considering Scale}

Over the past few decades, conservation planning has broadened to the landscape scale (i.e., transboundary) to address goals and wicked problems alike (e.g., climate change-oriented planning) [15-17]. Landscape-scale PPA management initiatives have correspondingly emerged (e.g., U.S. National Park Service's 2014 Scaling Up Initiative). The importance of transboundary conservation and landscape connectivity is evident through the International Union for Conservation of Nature, World Commission on Protected Areas' Transboundary Conservation Specialist Group and the Conservation Connectivity Specialist Group. Both represent hundreds of domestic and international initiatives working toward conservation goals.

Associated governance challenges to scaling up have been noted, including managing stakeholder interactions [18], accountability [19], and power differentials [20]. Scale mismatches (e.g., governance versus conservation extent, funding/political timelines versus conservation immediacy) exasperate these challenges $[17,18]$. Scaling up VUM data to the regional or national scale often occurs by synthesizing data collected for a particular agency's sites, drawing from park-specific studies. Notable examples include the U.S. National Forest Service's National Visitor Use Monitoring survey, U.S. National Park Service's Socioeconomic Monitoring program, and Statewide Comprehensive Outdoor Recreation Plans (SCORP) [21]. Integrating recreation data across agencies has been examined to improve natural resource management.

These multi-scalar efforts inform further investigation and practical application within VUM. However, the discipline currently lacks an integrated, adaptable model. VUM topical categories are 
often organized by the threefold framework of dimensions of a recreation site-managerial, resource, and social considerations [2]. Spatial scales are represented within the ROS [22], which examines the availability of particular recreation opportunities within/across PPAs on a wilderness-to-urban spectrum. Recent work, such as the Protected Destination System by Miller et al. (2018), further conceptualizes the spatial scale of recreation to encompass gateway regions linking PPAs [23]. Temporal distributions of PPA visitor use have been widely studied, with general patterns established at the scale of individual features (e.g., a scenic vista on a hiking trail) and on the short and medium temporal scales (e.g., visitor use peaking during weekends and the summer) [24]. Yet, no single conceptual model exists to guide the examination of VUM as an integrated SES across multiple types of scales.

\section{Research Need and Proposed Integrated Model}

In September 2018, a VUM research workshop was hosted by Clemson University's Department of Parks, Recreation, and Tourism Management. The overarching goals of this workshop were identifying unresolved issues in our discipline and working toward collaborative solutions. Approximately thirty experts in VUM science attended, mostly academics and consultants, along with many Clemson graduate students. Our multi-institution author team focused on identifying collaborative solutions related to the issue of "VUM scales of inquiry," in a break-out session of the workshop. We identified that, as a discipline, VUM critically needs a conceptual framework to integrate scales and topical dimensions as well as address interdisciplinary research questions and wicked problems. To work toward an applicable and scalable VUM systems model, a fundamental consideration is creating a base model with typologies. As a first step, we introduce a multi-scalar conceptual model for VUM containing topical aspects ("wedges") organized within dimensions of the threefold framework of VUM [2] (Figure 1). The narrower end of each wedge represents smaller spatial scales, with scale increasing toward the wider end of the wedge (Figure 1a). These wedges are three-dimensional, acknowledging that relationships exist among spatial and temporal scales (Figure 1b). The specific wedges included in the model are research topics that currently dominate VUM studies and literature across U.S. PPAs. The wedges also reflect the expertise of our disciplinarily diverse author team. Several "empty" wedges illustrate that this conceptual model may be adapted to include additional aspects that, at the time of publication, are not dominant in the VUM literature. Other wedges may not exist yet, as future technology could redefine or expand what "resource" and "visitor use" mean and thus necessitate a new wedge. These empty wedges provide opportunity for this model to be applicable, inclusive, and expansive beyond current VUM research trends and the expertise of this author team.

We contend that VUM research has largely focused on the center and shallow part of this model: Many studies are site-specific and of short duration. To expand the focus of VUM research, we suggest contributions are needed at broader scales. Such studies could provide valuable information for managing VUM systems, integrating VUM further into SES, and addressing related questions.

The proposed model is important for catalyzing discussion about VUM topical, spatial, and temporal scales of inquiry. In the following sections, we briefly describe each dimension and aspect's main attributes, primary research areas, and future directions. Rather than an exhaustive literature review, a few significant research examples illustrate each aspect. The authors of each section were paired based on expertise in different VUM aspects. For each aspect, the authors individually reviewed the literature related to their area of research focus within VUM, and then collectively selected examples that recognized foundational and contemporary research and demonstrated the aspect's complexity and diversity. In this manner, we summarize work illustrating what each aspect encompasses and provide references for deeper inquiry. Tables 2-4 present further details and examples of research for each aspect and scale. Table 2 provides examples of different spatial scales (small, medium, large) and temporal scales (short, medium, long) of investigation. Table 3 (spatial) and Table 4 (temporal) provide specific examples of existing and potential implementation of VUM research at these different scales. This work is framed primarily in the U.S. context, with international examples (e.g., international 
PPA categories) as appropriate. We encourage further reflection on relationships among aspects, dimensions, and scales (e.g., international, long-range goals) for VUM researchers and managers to consider meaningful, multi-scalar inquiries. We suggest that considering the components of our model when initiating a project and planning the research design allows for identifying opportunities for multi-scalar and interdisciplinary research. Through this explicit consideration, implementation of these opportunities (i.e., the next stage of "how") may become more apparent.

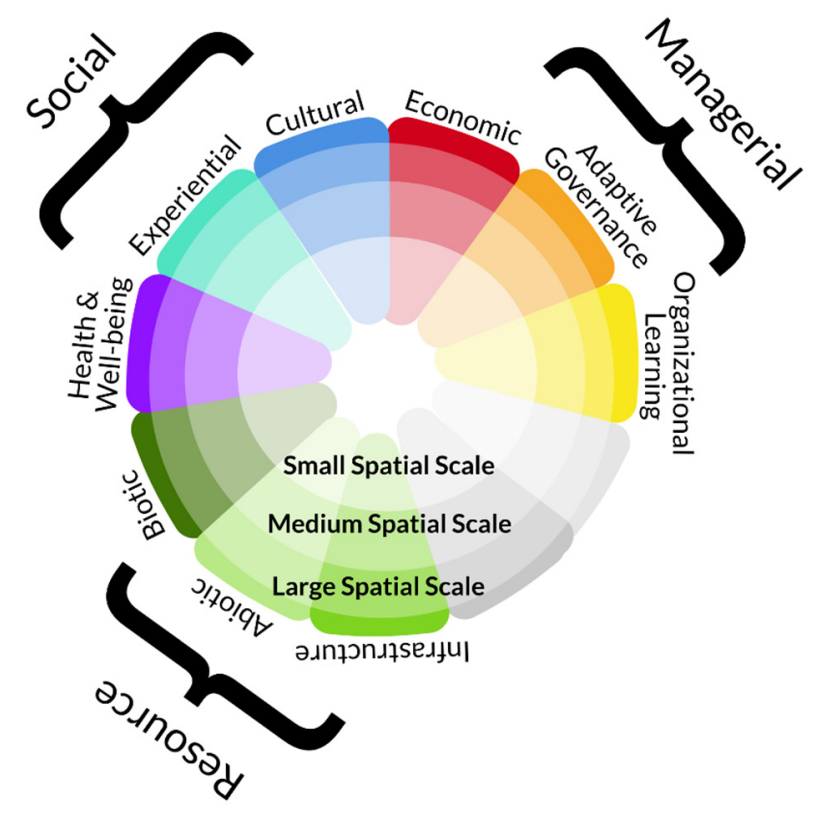

(a)

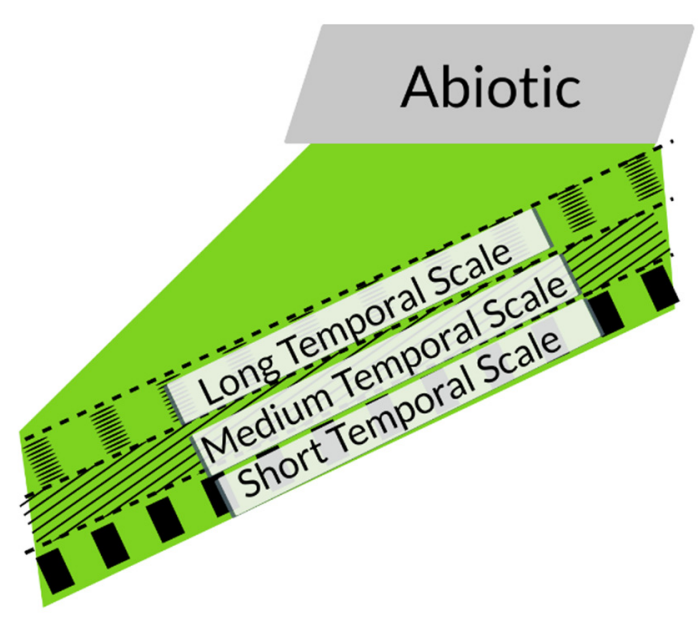

(b)

Figure 1. Cont. 


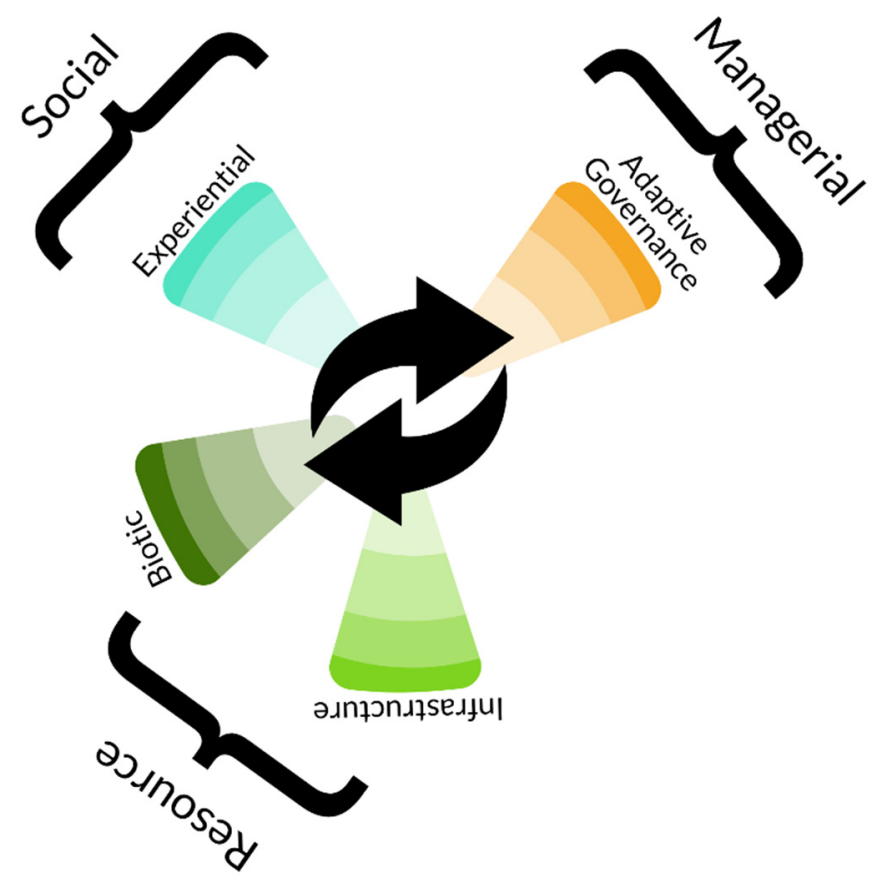

(c)

Figure 1. Three-dimensional conceptual model illustrating Visitor Use Management (VUM) research topics at varying yet interconnected spatial and temporal scales. This model is meant to guide future multi-scalar VUM research. Each topical aspect is represented by a wedge, with unlabeled gray wedges acknowledging additional and emergent aspects. Spatial scales are represented by width (a) and temporal scales are represented by height (b), with the Abiotic topical aspect as an example. Multiple wedges, and the relationships between them, can be explored across scales within a single study to address complex and interdisciplinary VUM research questions (c).

\subsection{Managerial Dimension}

PPA managerial components connect them to systems of governance. Within this dimension, adaptive governance, economics, and organizational learning aspects are highlighted for their influences on VUM functioning and hierarchical sets of policies and changes over time. Although PPAs are usually stand-alone units with particular management strategies, linkages to larger systems (e.g., state parks, national forests) allow for scalable approaches to issues. Hind and foresight have often been approaches to instituting sound adaptive governance, economic resilience, and organizational learning across longer temporal scales. The following section details these three aspects in more detail, with examples of scales in which VUM research has mainly focused. Through inspection of how scale issues have previously been broached, we can deepen insight on how to consider them going forward.

\subsubsection{Adaptive Governance}

Adaptive governance requires recognizing change as continuous and unavoidable [25]. Flexible management strategies can help institutionalize approaches to change by incorporating SES and scale-explicit management approaches [26]. Although organizational capacity may require simplifying SES (e.g., focusing on one policy area at a time), adaptive management recognizes institutional flexibility, openness to fresh ideas, acknowledgement of policy failures, and grounding on long-term considerations as approaches to complex systems management [27]. It also emphasizes clear responsibilities and leadership [26,28] and experimental learning to reduce uncertainty [29].

Effective adaptive management should incorporate multiple scales and be supported by related multi-scalar policies. VUM research, however, has tended to focus on unit-level, limited-duration management plans. These small-scale and bottom-up approaches are necessary $[27,29,30]$. For example, 
empowering individual employees to engage in short, informal, and sometimes spontaneous projects toward a broader goal can promote complexity thinking [27-29]. An important medium scale sits on the way toward SES management: incorporating the long-term quest for changes to planning on both a regional scale and for near-future scenarios [25,31,32]. These medium scale approaches can integrate and reconcile the pros and cons of the smaller scale (pro: area of managerial action; con: fragmentation) with the larger scale (pro: unity of jurisdiction; con: remote center) by facilitating connections spatially [33] and socially (e.g., between managers and scientists) [30]. Examining these medium approaches and their role in organizational learning remains an area of further investigation in VUM.

\subsubsection{Economic}

VUM economic analyses are a well-established tradition [34,35]. Many topics have been examined, including demand, consumer surplus, cost, pricing, valuation, and impacts [36]. Contingent valuation [37] and travel cost [38] analyses are common methods. Not every PPA or agency can collect original data, so methods for transferability of site-level research [39] and temporal stability of these data [40] have also been assessed.

Most studies have been conducted at the scale of an individual site, but some have focused on multi-destination trips [41] and regional or national economic impact assessments [42,43]. Regional impact assessments examine how direct recreation expenditures and secondary economic impacts reverberate across the economy (multiplier effect). The largest economic demand survey, the U.S. Fish and Wildlife Service's NSFHWAR, has gathered information on five-year cycles since 1955 on participation and expenditures on fishing, hunting, and wildlife viewing on PPAs [44]. Large samples and spatial stratifications allow for state and regional comparisons, user group segmentations, and evaluations of national trends. Some states completing SCORP collect economic impact data but without consistent methodology. Very few economic studies have been conducted on regional systems of economic opportunities.

\subsubsection{Organizational Learning}

Organizational learning is integral to sustained organizational success [45]. It occurs as an organization acquires transformational experiences [45]. Organizational learning links strategic leadership, innovation, and performance, internally and externally [46,47]. Crossan's foundational framework premises that scales of organizational learning are influenced by differing processes: Individual learning occurs through intuiting and interpreting, group learning occurs through integrating, and organizational learning occurs through institutionalizing (i.e., systems rules and policies) [48]. Additionally, organizational learning can occur from bottom-up or top-down interactions, resulting in different management and behaviors [45].

In VUM, organizational learning occurs across scales (Tables 3 and 4). To promote learning, organizations encourage employees to acquire knowledge (e.g., training), disseminate it, and preserve and update systems of institutional memory [47]. Some research has explored VUM organizational learning across U.S. Forest Service lands [49] and U.S. Army Corps of Engineers' lakes [28] and internationally in other PPA systems [50]. Other studies have focused on specific challenges including wildfire management [51] and state-wide PPA interagency workings [52]. Overall, limited studies investigate organizational learning over longer temporal scales in general and within VUM specifically.

\subsection{Resource Dimension}

Most PPAs have resource conservation-related mandates or policies (e.g., U.S. National Park Service dual mandate, U.S. Fish and Wildlife Service mission). Additionally, many federal policies (e.g., U.S. Endangered Species Act) emphasize resource protection. Despite these, visitor use can and does impact PPA ecosystems and their components [53]. A key area of VUM is to understand, manage, and mitigate impacts to PPAs' resources. VUM's resource dimension encompasses three interrelated 
aspects: biotic, abiotic, and infrastructure. PPA ecosystems encompass abiotic and biotic components, while infrastructure encompasses manager- and visitor-induced manipulations of these ecosystems. Infrastructure (e.g., trails, campsites) allows for recreational access and quality visitor experiences. Biotic, abiotic, and infrastructure aspects function across spatial (localized/individual to global) and temporal scales (days/weeks to decades or eons). VUM research and subsequent management actions have occurred at varied spatial scales [54], but relatively short temporal scales (though exceptions exist, e.g., [55-57]). The following details these aspects and how multi-scalar research can contribute in managerially-meaningful ways.

\subsubsection{Abiotic}

Many PPAs were established to protect abiotic resources and geodiversity (e.g., physical landscapes, natural processes) [58]. Conditions of the physical environment, such as natural sounds and dark skies, are also considered abiotic resources. Conservation values are expressed from single iconic landform features (e.g., the Delicate Arch in Arches National Park) to broad landscape-scale processes (e.g., volcanism in Hawaii Volcanoes National Park). Many physical landscapes and processes are increasingly threatened by anthropogenic climate change.

VUM research has focused on abiotic resources in several ways. Recreation ecology research has documented how visitor use can alter physical processes, such as accelerated soil erosion and sedimentation $[53,59,60]$. Many investigations have been conducted on limited scales [54]. Fewer document visitor use impacts at broader scales, such as landscape fragmentation from off-road vehicle tracks [61] or informal trails [62] and long-term effects in landscape disturbance [55-57]. Abiotic VUM research has examined visitor impacts, perceptions, experiences, and management preferences from specific features (e.g., waterfalls, sand dunes) to overall landscapes [63]. Studies are largely based on surveys administered at locations within a PPA, and thus, their sampling frames are often spatially and temporally limited. Significant knowledge gaps remain on relationships among abiotic resources and VUM at multiple scales, including how local PPA impacts from visitors may affect broader resources due to off-site effects and altered visitor spatial behavior.

\subsubsection{Biotic}

Ecosystem biota in PPAs include all living organisms (e.g., wildlife, insects, plants). Biotic processes and impacts from visitor use are complex scale-dependent processes [64] occurring through a variety of mechanisms [53]. Impacts to a single biotic ecosystem component can cascade and aggregate across scales over time. For example, small impacts to vegetation can lead to informal trails forming. If prolific, these can then cause habitat fragmentation [65], which in turn can impact habitat connectivity and ultimately influence PPA biodiversity over longer temporal scales [66].

Humans are part of the biotic factors in PPAs but our scales of recreation vary alongside other biota [54]. For example, impacts to biota that function at relatively small spatial scales (e.g., insects, herpetofauna) are largely understudied [67]. Studies on recreation impacts to wildlife have largely focused on individual-level impacts versus population or community-level relationships [68]. Without comprehensive understanding of how visitor use impacts biota at multiple scales, managers may not be effective in mitigating these impacts.

\subsubsection{Infrastructure}

Infrastructure is a key component of PPAs. Properly sited, developed, and maintained roads, trails, campsites (individual sites), campgrounds (clusters of sites), and other recreation infrastructure can provide long-term protection of a PPA's natural resources, improve visitor access, and offer diverse and sustainable experiences [2,53]. Individual infrastructure components combine to create intra-PPA networks and systems of recreation access and experience. In many cases, these systems connect to create inter-PPA boundary mosaics and networks (e.g., national scenic trails). Studies focusing on single trail segments and transects inform design, construction, and management considerations for 
PPA managers and stewards (e.g., [69]). Similar research on individual camp and recreation sites has led to greater understanding of the variables driving impacts to natural resources and visitors' desires for related experiences $[70,71]$. Other research has examined broader scales, such as relationships between visitor experience and resource conditions along the Appalachian National Scenic Trail [72,73].

Sustainability research related to infrastructure integrates managerial, social, and resource protection lenses but often examines use and impacts at short (i.e., hourly to daily) and medium (i.e., seasonal or yearly trends) scales [74]. A few studies have examined longer duration changes in campsites $[57,75,76]$, but long-term studies examining other recreation infrastructure (e.g., roads, trails) are largely lacking. Disparities exist between the scale of natural systems and cycles and the scale at which VUM infrastructure research is occurring. For example, soil erosion is a natural process that shapes landforms, but how this process is influenced by developing and maintaining associated infrastructure is not well-understood. Recognizing that abiotic and biotic systems often function and respond on multiple scales, future research should better integrate studies on these systems and the multi-scalar relationships between visitor use, infrastructure, and ecosystems.

\subsection{Social Dimension}

PPA's social aspects center on benefits accrued to visitors (e.g., health, experiences, learning). Though, intuitively, these benefits are understood on scales beyond the visitor (e.g., communities, specific populations, society) and beyond the visit (e.g., lifelong health and learning, preserved history), research often does not address these beyond-visitor and beyond-visit scales. PPA's recreation-related physical and mental health impacts are a current focal area, as is understanding experiences available and histories preserved across PPA systems. This research acknowledges the diverse social, administrative, and resource protection purposes of PPAs [77-79] and the need for multi-scalar inquiries. Investigations at longer time scales remain sparse. The following section describes aspects of the social dimension, illustrates research trends, and identifies particular scales for further contribution.

\subsubsection{Health and Well-Being}

Recreation in PPAs supports benefits including physical and mental health and well-being. The nexus between the outdoors and health has inspired initiatives such as Healthy Parks, Healthy People and Park Prescriptions, and has engaged diverse partners locally to nationally. Physical health can be supported by PPA recreation of varying duration and intensity [80-82]. For example, health benefits reported from PPA recreation include improved cardiovascular health, muscle strength, endurance, and respiratory health, along with decreased obesity and blood pressure [82].

Mental well-being has been a prominent area studied in PPAs. The World Health Organization defines well-being as a state where an individual realizes their abilities, copes with normal life stresses, works productively, and contributes to their community [83]. Considering this broad definition, PPAs provide for well-being as an ecosystem service [84] across the wilderness-to-urban ROS (e.g., [82,85,86]). Mental well-being indicators have been associated with actually visiting a PPA [87], viewing images of one [88,89], or hearing sounds from PPAs [90]. An individual may experience enhanced well-being by simply valuing a PPA, even if they never physically visit it [91].

Recreation in all PPAs holds potential for contributing to physical and mental health and well-being. However, limited research has investigated public lands and non-urban green spaces [82]. Some long-term assessments of health impacts from recreation in natural settings exist, particularly for those suffering from severe mental health issues, (e.g., [92,93]), but overall, there are limited longitudinal studies for health outcomes in PPAs [82].

\subsubsection{Experiential}

People visit PPAs to have experiences (e.g., recreational, educational, cultural, spiritual, scientific). Providing opportunities for these experiences is a common mission of virtually all PPAs and the center of VUM. Three main experiential spatial scales exist: the individual (i.e., 
single to small groups of visitors and their personal experiences), the site where individuals seek experiences, and the system of aggregated sites (e.g., landscape-wide, regional, national, internationally) [22,94]. Successful VUM at each scale requires providing diverse opportunities that both satisfy individuals' desires while respecting site constraints and reflecting PPAs' democratic and aspirational purposes [95]. Visitor experiences span temporal scales too, from an individual experience, to collections of experiences unfolding over time with anticipation and planning, travel to/from, and later reflection/recounting [34]. These processes aggregate, with individuals and groups building experience, history, and attachment [96]. Places also accumulate experiential character over time [97], such as a PPA becoming known as a "family-friendly" or "experts-only" backpacking destination.

Experiential research addresses scales in focused and integrated ways. This is true at the smallest scale, with visitors' individual outcome attainment through particular experiences [94] to the societal level [98]. Individual experiences, leading to and during PPA visits, are being integrated into site management, including the added perspectives of regional comparison $[99,100]$. Researchers should focus on harnessing this broad and deep body of work to answer managers' needs across dimensions and scales.

\subsubsection{Cultural}

PPAs of all types, including large wildlands, serve cultural purposes, often providing critical opportunities for continuing resource-dependent practices [101]. The cultural functions of PPAs extend beyond their immediate communities. In modern-day U.S. culture, PPAs serve important purposes related to national identity and pride [102], as well as different meanings to specific populations [103]. Most cultural PPAs are constructed around past events or phenomena, but contemporary factors (e.g., climate, social, land use changes) shape/reshape the meaning and structure of cultural PPAs and their modes of preservation and interpretation [104,105]. Complex scale issues emerge within an individual's visit, as cultural PPAs facilitate multiple levels of engagement within this visit [106]. This suggests that researchers must contend with multi-scalar complexity when investigating cultural aspects of PPAs.

Although cultural PPA designations account for almost half of U.S. National Park Service sites, relatively few studies have examined collections of sites, National Heritage Areas, or full lengths of historic trails [107-109]. These examples invite VUM research, with their ability to bridge an individual site and regional identity, a discrete event and societal change, and recreation and other ecosystem services [110]. U.S. participation in the UNESCO Man and the Biosphere program emphasizes relationships between sustaining livelihoods and natural resources, allowing for examinations of large-scale systems and identities, but political resistance has constrained research potential [111]. The U.S. National Park Service has enacted studies of particular themes (e.g., Underground Railroad resources, labor rights, LGBTQ recognition) that may expand a narrative from a point-in-time to timeless [112], yet VUM research has yet to focus on examining related visitor engagement over time. VUM research on larger scales could help identify themes and approaches to increase site appeal and relevance to new generations [113], as well as better understand common human narratives.

\section{Discussion}

In this manuscript, we present an integrated conceptual model (Figure 1 and Table 2) for examining VUM inquiries across scales. Such examinations are necessary precursors to expanding the discipline's theoretical contributions, collaborative potential, managerial utility, and understanding of related complex interactions and systems. It is important to recognize that each of the aspects within the managerial, resource, and social dimensions are interrelated and research studies should consider inclusion of diverse dimensions and aspects in the study design. For example, within the managerial dimension, adaptive governance is challenged by a lack of flexibility, especially beyond park boundaries where there is an absence of policy to guide this adaptive approach and support organizational learning on-the-ground. Additionally, researchers addressing complex issues in the field should also consider 
integration across dimensions such as inclusion of both social and resource aspects for human-wildlife conflicts (Figure 1c). In the following sections, we synthesize and discuss the spatial, temporal, and integrated considerations of this model.

\subsection{Spatial Scale across Dimensions}

The VUM conceptual model includes dimensions and aspects that can be addressed at small, medium, and large spatial scales (Tables 2 and 3). Within VUM, managerial aspects are often addressed at the smaller spatial scale (e.g., a specific PPA or its staff). The broad-scale nature of managerial aspects has lent itself to research that tends to be bimodal, focusing on the site or the state/national level. The medium range, between local and state/national scales, has been of lesser focus yet is an important consideration for assessing trends and implementing approaches across regional PPAs. Some studies have addressed site-specific, state, and national economic trends (e.g., [42,43]), but fewer have addressed these scales for adaptive governance and organizational learning.

The resource dimension includes aspects that can be addressed at varying spatial scales and indeed, have been more so than those in the managerial and social dimensions. The shift toward large landscape and transboundary strategies acknowledges that these resources transcend geographical, institutional, and political boundaries [15-17]. Despite recognizing that resources require management at larger spatial scales (e.g., long-distance trails, migratory wildlife), most VUM studies focus on local or site-specific resources. This limitation applies to infrastructure that extends beyond PPA boundaries (e.g., roads, long-distance trails).

The social dimension has a similar pattern of study. There are limited health and well-being studies for PPAs and fewer for VUM [82]. Similarly, VUM's experiential aspects are often studied as individual experiences in single visits to PPAs and viewed with limited generalizability to larger PPA and VUM contexts. Lastly, cultural aspects of VUM often are studied at a small scale and do not often integrate the regional landscape and culture (with research on the U.S. National Park Service's National Heritage Areas providing a notable exception).

\subsection{Temporal Scale across Dimensions}

Temporal scales offer an opportunity to examine the VUM conceptual model across time periods (Tables 2 and 4). Shorter duration examinations in the managerial dimension include informal connections among staff to support adaptive governance, one-time economic studies, and dialogue among staff at a site to support organizational learning. As the duration increases, scenario planning can help support adaptive governance and organizational learning, and repeated economic assessments of VUM can assess trends. Some studies have explored the temporal stability of recreation values $[40,44]$ but there is a greater need for long-term studies focused on organizational learning and adaptive governance. Extending research beyond the immediate fiscal year or current administration's planning needs can position VUM for a sustainable future.

The resource dimension includes opportunities to examine time-sensitive impacts related to PPA ecosystems' abiotic and biotic components and infrastructure. Most studies have focused on short-term recreational impacts to inform resource management. There is a dearth of research assessing trends in impacts over decades or longer. Additionally, limited studies have focused on population or community-level impacts to a species [68], which may also take decades to assess.

The social dimension also lacks temporal diversity. Health and well-being research can range from someone's heart rate during a single PPA visit to their overall heart health over decades of visiting a PPA, particularly for those suffering from severe mental health issues, (e.g., [92,93]). Many long-term health studies transcend an individual's lifetime and sociological studies examine cultures over decades or centuries, but limited research exists in these aspects as related to VUM. Additionally, there is a need to expand temporally to understand the depth and uniqueness of VUM experiences beyond satisfaction studies. 
Despite the diversity and plethora of scale-transcending studies in many other disciplines, the VUM discipline is lacking multi-scalar research in its managerial, resource, and social dimensions. While units of scale are discipline-specific, the need to engage across scales is critical for any scientific discipline to inform management and policy. To advance VUM, we propose integrating spatial and temporal scale research within and across its dimensions to effectively strengthen the foundational concepts and theories within VUM research, and support management and policy that thoughtfully integrate systems thinking.

\subsection{A Call to Action: Integrating Scales across Dimensions}

VUM relies on research and studies to inform managerial decision-making. Complex SES underlay the function and management of PPAs, their ecosystems and the recreational and conservation programs administered within. These natural, cultural, and societal systems span boundaries and time, resulting in complex interconnected relationships. For research to better meet managers' VUM needs, studies and examinations of past research need to look beyond study and park boundaries to explore these varied spatial and temporal interactions and systems.

To this end, Figure 1 presents a conceptual model to structure the spatial and temporal bounds related to the intersection of complexity and utility. Thus, this model represents the need to consider a z-axis, or third dimension, in all VUM inquiries. Historically, PPA VUM research has been concentrated close to the core of this three-dimensional model-investigations within a topical aspect that are of relatively small spatial and short time scales (Tables 1-3). While investigations at these scales are necessary, there is a need to integrate the complexity of a z-axis and relatively larger spatial and longer time scales into research while maintaining managerial specificity.

Researchers and managers need to conduct studies that ask critical questions:

- What spatial and temporal scales are relevant to the issue or topic being studied?

- What portion(s) of an SES am I exploring?

- Can I adjust scale or study design to better integrate with additional studies or SES?

Employing such questioning within research studies can start to normalize multi-scalar thinking in VUM. Leveraging these questions at the beginning of studies can help identify ways to structure research at the narrow end of a wedge in the model to incorporate landscape-level thinking and cross-project longitudinal data repositories.

After asking these key questions, researchers need to conduct interdisciplinary, multi-scalar VUM research. For each VUM topic, the smaller and shorter scales are often robustly researched, therefore, there is a need for scaling up within research design and integration across scales. For example, research within the medium scales could benefit by both spring-boarding from this nested approach to meet PPA managers' discrete needs and bridging the larger and longer scales for a holistic understanding of VUM trends. The medium scale could include PPAs such as heritage landscapes and ecosystem-level conservation and lengths of time beyond a single year. VUM research at corresponding scales will allow for explorations of regional groupings of PPAs according to resource similarities. These explorations may tackle critical questions as-yet unaddressed, such as how these PPAs function together within a SES for managerial plans, conservation needs, and visitor experiences. In this way, research within the medium scales may sharpen the focus of these far-reaching inquiries into areas for regional collaborative action and multi-case study contribution.

The medium scale example is but one area of potential for multi-scalar VUM research. More than promoting a particular focal scale, we reiterate the need for researchers to be scale-aware and scale-actionable throughout the lifespan of their projects:

- Match the scale of research questions to the scale of the issue;

- Invite managers, other researchers, and policymakers to consider complementary scales;

- Employ methods that best suit the scales in question; 
- Identify tools that assist in multi-scalar thinking; and

- Create broader systems of knowledge (e.g., data repositories) to encourage VUM research extending beyond the capacity of one career or one PPA.

A discipline-wide commitment to these approaches will move VUM research from concentrated approaches toward a more integrated, interdisciplinary, and multi-scalar science. Furthermore, such considerations acknowledge the imperative for continued work in scaling up. This provides an opportunity to intersect with and draw inspiration from other disciplines, highlight the contributions of VUM work beyond park boundaries, and address the larger questions challenging our discipline.

\subsection{Challenges of Transcending Scales in VUM Research}

This manuscript identifies a call to action among researchers and practitioners in VUM; however, it is important to acknowledge the challenges of transcending spatial and temporal scales in research. Some of these challenges relate to funding, as VUM research funding is short-term and rarely allows for longitudinal studies. Additionally, funding is often tied to budgets of specific PPAs and not regional or system scales, making it difficult for researchers to conduct studies beyond individual PPAs. Secondly, research at the system scale or that addresses shifts in culture or long-term impacts takes substantial time. Yet, most managers and decision-makers operate at a shorter time scale, making it difficult to have long-term research inform short-term decisions [114]. Third, integration of research across the dimensions and scales will require transdisciplinary teams. Specific skills and training are often needed to effectively and efficiently converge diverse fields of science [115]. Lastly, there may be tension or complementarity among the different dimensions that can influence the focus and outcomes of research in VUM. These tensions may raise critical questions when integrating across dimensions and scales. For example, how do social aspects of the visitor experience have long-term impacts on local culture and the natural resources? How does resource use at the local scale create tension with conservation of a species at a system scale? How do economic aspects of VUM conflict or complement recreational access for locals and visitors?

Author Contributions: Conceptualization, All authors; methodology, All authors; formal analysis, All authors; investigation, All authors; resources, All authors; data curation, All authors; writing-original draft preparation, All authors, led by E.E.P., J.M.T., A.L.D. and W.C.M.; writing—review and editing, All authors, led by E.E.P., J.M.T., A.L.D. and W.C.M.; visualization, A.L.D.; citation management, W.C.M.; supervision, E.E.P., J.M.T. and A.L.D.; funding acquisition, E.E.P. All authors have read and agreed to the published version of the manuscript.

Funding: This research received no external funding beyond an APC reduction by Oregon State University through its membership in MDPI's Institutional Open Access Program.

Acknowledgments: This manuscript builds on discussions among park and protected area social scientists during a Visitor Use Management workshop at Clemson University in September 2018. This workshop was sponsored by Clemson University's Department of Parks, Recreation, and Tourism Management (PRTM). We thank them for providing this collaborative space and continued support.

Conflicts of Interest: The authors declare no conflict of interest.

\section{References}

1. Interagency Visitor Use Management Council (IVUMC). Visitor Use Management Framework: A Guide to Providing Sustainable Outdoor Recreation. Available online: https:/visitorusemanagement.nps.gov/VUM/ Framework (accessed on 30 July 2020).

2. Manning, R.E. Studies in Outdoor Recreation: Search and Research for Satisfaction, 3rd, ed.; Oregon State University Press: Corvallis, OR, USA, 2011.

3. Berkes, F.; Colding, J.; Folke, C. Navigating Social-Ecological Systems: Building Resilience for Complexity and Change; Cambridge University Press: Cambridge, UK, 2003; p. 393.

4. Cillers, P.; Biggs, H.C.; Blignaut, S.; Choles, A.G.; Hofmeyr, J.-H.S.; Jewitt, G.P.W. Complexity, modeling, and natural resource management. Ecol. Soc. 2013, 18, 10. [CrossRef] 
5. Levin, S.A. Fragile Dominion: Complexity and the Commons; Perseus Books: Reading, MA, USA, 1999.

6. Allen, T.F.H.; Hoekstra, T.W. Toward a Unified Ecology; Columbia University Press: New York, NY, USA, 1992.

7. $\mathrm{Wu}, \mathrm{J} . ;$ Loucks, O.L. From balance of nature to hierarchical patch dynamics: A paradigm shift in ecology. $Q$. Rev. Biol. 1995, 70, 439-466. [CrossRef]

8. Gunderson, L.H.; Holling, C.S. Panarchy: Understanding Transformations in Human and Natural Systems; Island Press: Washington, DC, USA, 2002.

9. O’Neill, R.V.; King, A.W. Homage to St. Michael; or, Why are there so many books on scale? In Ecological Scale: Theory and Applications; Peterson, D.L., Parker, V.T., Eds.; Columbia University Press: New York, NY, USA, 1998.

10. McCool, S.F.; Kline, J.D. A Systems Thinking Approach for Thinking and Reflecting on Sustainable Recreation on Public Lands in an Era of Complexity, Uncertainty, and Change; USDA Forest Service, Pacific Northwest Research Station: Portland, OR, USA, 2020; pp. 161-172.

11. Morse, W.C. Recreation as a social-ecological complex adaptive system. Sustainability 2020, 12, 753. [CrossRef]

12. Morse, W.C. Payments for Environmental Services in Costa Rica: Conservation and Production Decisions within the San Juan—La Selva Biological Corridor. Ph.D. Thesis, University of Idaho, Moscow, ID, USA, 2007.

13. Stones, R. Structuration Theory; Palgrave Macmillan: New York, NY, USA, 2005.

14. Morse, W.C.; Hall, T.E.; Kruger, L.E. Improving the integration of recreation management with management of other natural resources by applying concepts of scale from ecology. Environ. Manag. 2009, 43, 369-380. [CrossRef]

15. Tabor, G.M.; Carlson, A.; Belote, T. Challenges and Opportunities for Large Landscape-Scale Management in a Shifting Climate: The Importance of Nested Adaptation Responses Across Geospatial and Temporal Scales; US Department of Agriculture, Forest Service; Rocky Mountain Research Station: Fort Collins, CO, USA, 2014; pp. 205-227.

16. Bixler, R.P.; Johnson, S.; Emerson, K.; Nabatchi, T.; Reuling, M.; Curtin, C.; Romolini, M.; Grove, J.M. Networks and landscapes: A framework for setting goals and evaluating performance at the large landscape scale. Front. Ecol. Environ. 2016, 14, 145-153. [CrossRef]

17. Baldwin, R.F.; Trombulak, S.C.; Leonard, P.B.; Noss, R.F.; Hilty, J.A.; Possingham, H.P.; Scarlett, L.; Anderson, M.G. The future of landscape conservation. BioScience 2018, 68, 60-63. [CrossRef]

18. Guerrero, A.M.; McAllister, R.R.; Corcoran, J.; Wilson, K.A. Scale mismatches, conservation planning, and the value of social-network analyses. Conserv. Biol. 2013, 27, 35-44. [CrossRef]

19. Jedd, T.; Bixler, R.P. Accountability in Networked Governance: Learning from a case of landscape-scale forest conservation. Environ. Policy Gov. 2015, 25, 172-187. [CrossRef]

20. Wyborn, C. Cross-scale linkages in connectivity conservation: Adaptive governance challenges in spatially distributed networks. Environ. Policy Gov. 2015, 25, 1-15. [CrossRef]

21. English, D.B.K.; Kocis, S.M.; Zarnoch, S.J.; Arnold, J.R. Forest Service National Visitor Use Monitoring Process: Research Method Documentation; GTR-SRS-057; USDA Forest Service, Southern Research Station: Asheville, NC, USA, 2002.

22. Clark, R.N.; Stankey, G.H. The Recreation Opportunity Spectrum: A Framework for Planning, Management, and Research; GTR-PNW-98; United States Department of Agriculture Forest Service: Pacific Northwest Forest and Range Experiment Station: Corvallis, OR, USA, December 1979; p. 32.

23. Miller, M.L.; Lieske, S.N.; Carter, R.W.; Walsh, S.J. Understanding the interaction between a protected destination system and conservation tourism through remote sensing. In Comprehensive Remote Sensing; Liang, S., Ed.; Elsevier: Amsterdam, The Netherlands, 2018; pp. 123-143.

24. Goulding, P. Managing temporal variation in visitor attractions. In Managing Visitor Attractions: New Directions, 2nd ed.; Fyall, A., Garrod, B., Leask, A., Wanhill, S., Eds.; Butterworth-Heinemann: Oxford, UK, 2008; pp. 197-216.

25. Selberg, M.M.; Ryan, P.; Borgstrom, S.T.; Norstrom, A.V.; Peterson, G.D. From resilience thinking to resilience planning: Lessons from practice. J. Environ. Manag. 2018, 217, 906-918. [CrossRef]

26. Dutra, L.X.C.; Bustamante, R.H.; Spone, I.; van Putten, I.; Dichmont, C.M.; Ligtermoet, E.; Sheaves, M.; Deng, R.A. Organizational drivers that strengthen adaptive capacity in the coastal zone of Australia. Ocean Coast. Manag. 2015, 109, 64-76. [CrossRef]

27. Ascher, W. Coping with complexity and organizational interests in natural resource management. Ecosystems 2001, 4, 742-757. [CrossRef] 
28. Salk, R.J.; Schneider, I.E. Commitment to learning within a public land management agency: The influence of transformational leadership and organizational culture. J. Park Recreat. Adm. 2009, 27, 70-84.

29. Dunning, K.H. Missing the trees for the forest? Bottom-up policy implementation and adaptive management in the US natural resource bureaucracy. J. Environ. Plan. Manag. 2017, 60, 1036-1055. [CrossRef]

30. Fischer, A.P.; Vance-Borland, K.; Burnett, K.M.; Hummel, S.; Creighton, J.H.; Johnson, S.L.; Jasny, L. Does the social capital in networks of "fish and fire" scientists and managers suggest learning? Soc. Nat. Resour. 2014, 27, 671-688. [CrossRef]

31. Raymond, C.M.; Cleary, J. A tool and process that facilitate community capacity building and social learning for natural resource management. Ecol. Soc. 2013, 18, 25. [CrossRef]

32. Knapp, C.L.; Fresco, N.; Krutikov, L. Managing Alaska's national parks in an era of uncertainty: An evaluation of scenario planning workshops. Reg. Environ. Chang. 2017, 17, 1541-1552. [CrossRef]

33. Lovell, C.; Mandondo, A.; Moriarty, P. The question of scale in integrated natural resource management. Conserv. Ecol. 2002, 5, 25. [CrossRef]

34. Clawson, M.; Knetsch, J.L. Economics of Outdoor Recreation; John Hopkins Press: Baltimore, MD, USA, 1969.

35. Loomis, J.B.; Walsh, R.G. Recreation Economic Decisions: Comparing Benefits and Costs; Venture Publishing: State College, PA, USA, 1997.

36. Plummer, R. Outdoor Recreation: An Introduction; Routledge: New York, NY, USA, 2009; p. 389.

37. Boyle, K.J. Contingent valuation in practice. In A primer on Non-Market Evaluation; Champ, P.A., Boyle, K.J., Brown, T.C., Eds.; Kluwer Academic Publishers: Boston, MA, USA, 2003; pp. 111-169.

38. Rosenberger, R.S.; Loomis, J.B. Benefit Transfer of Outdoor Recreation Use Values: A Technical Document Supporting the Forest Service Strategic Plan; RMRS-GTR-72; U.S. Department of Agriculture, Forest Service, Rocky Mountain Research Station: Fort Collins, CO, USA, 2001.

39. Johnston, R.J.; Rosenberger, R.S. Methods, trends and controversies in contemporary benefit transfer. J. Econ. Surv. 2010, 24, 479-510. [CrossRef]

40. Rolfe, J.; Dycak, B. Testing temporal stability of recreation values. Ecol. Econ. 2019, 159, 75-83. [CrossRef]

41. Loomis, J.B. A comparison of the effect of multiple destination trips on recreation benefits as estimated by travel cost and contingent valuation methods. J. Leis. Res. 2006, 38, 46-60. [CrossRef]

42. Poudel, J.; Munn, I.A.; Henderson, J.E. Economic contributions of wildlife watching recreation expenditures (2006 \& 2011) across the U.S. south: An input-output analysis. J. Outdoor Recreat. Tour. 2017, 17, 93-99.

43. Outdoor Industry Association. 2018 Annual Report; Outdoor Industry Association: Boulder, CO, USA, 2018.

44. USF\&WS. 2006 National Survey of Fishing, Hunting, and Wildlife-Associated Recreation; USF\&WS: Washington, DC, USA, 2017.

45. Argote, L.; Miron-Spektor, E. Organizational learning: From experience to knowledge. Organ. Sci. 2011, 22, 1123-1137. [CrossRef]

46. Vera, D.; Crossan, M.M. Strategic leadership and organizational learning. Acad. Manag. Rev. 2004, 29, 222-240. [CrossRef]

47. Jimenez-Jimenez, D.; Sanz-Valle, R. Innovation, organizational learning, and performance. J. Bus. Res. 2011, 64, 408-417. [CrossRef]

48. Crossan, M.M.; Lande, H.W.; White, R.E. An organizational learning framework: From intuition to institution. Acad. Manag. Rev. 1999, 24, 522-537. [CrossRef]

49. Brown, G.T.; Squirrell, T.G.; Harris, C.C. Growing organizational challenges for the US Forest Service: Results of a longitudinal study in a period of major environmental change. J. For. 2010, 108, 77-85.

50. Nkhata, B.A.; Breen, C. A framework for exploring integrated learning systems for the governance and management of public protected areas. Environ. Manag. 2010, 45, 403-413. [CrossRef]

51. Zimmerman, T.; Sexton, T. Organizational learning contributes to guidance for managing wildland fires for multiple objectives. Fire Manag. Today 2010, 70, 9-14.

52. Barlett, K.R.; McKinney, W.R. A Study of the role of professional development, job attitudes, and turnover among public park and recreation employees. J. Park Recreat. Adm. 2004, 22, 63-81.

53. Hammitt, W.E.; Cole, D.N.; Monz, C.A. Wildland Recreation: Ecology and Management, 3rd ed.; Wiley Blackwell: Chichester, UK, 2015.

54. Gutzwiller, K.J.; D’Antonio, A.L.; Monz, C.A. Wildland recreation disturbance: Broad-scale spatial analysis and management. Front. Ecol. Environ. 2017, 15, 517-524. [CrossRef] 
55. Cole, D.N. Long-term effectiveness of restoration treatments on closed wilderness campsites. Environ. Manag. 2013, 51, 642-650. [CrossRef] [PubMed]

56. Dixon, G. A longitudinal study of backcountry track and campsite conditions on the Overland Track, Tasmania, Australia. J. Outdoor Recreat. Tour. 2017, 19, 25-36. [CrossRef]

57. Eagleston, H.A.; Marion, J.L. Sustainable campsite management in protected areas: A study of long-term ecological changes on campsites in the boundary waters canoe area wilderness, Minnesota, USA. J. Nat. Conserv. 2017, 37, 73-82. [CrossRef]

58. Worboys, G.L.; Lockwood, M.; Kothari, A.; Feary, S.; Pulsford, I. Protected Area Governance and Management; Australian National University Press: Canberra, Australia, 2015.

59. Carothers, S.W.; Johnson, R.A.; Dolan, R. Recreational impacts on Colorado River beaches in Glen Canyon, Arizona. Environ. Manag. 1984, 8, 353-358. [CrossRef]

60. Marion, J.L.; Leung, Y.-F.; Eagleston, H.A.; Burroughs, K. A review and synthesis of recreation ecology research findings on visitor impacts to wilderness and protected natural areas. J. For. 2016, 114, 352-362. [CrossRef]

61. Welch, R.; Madden, M.; Doren, R.F. Mapping the Everglades. Photogramm. Eng. Remote Sens. 1999, 65, 163-170.

62. Leung, Y.-F.; Newburger, T.; Jones, M.; Kuhn, B.; Woiderski, B. Developing a monitoring protocol for visitor-created informal trails in Yosemite National Park, USA. Environ. Manag. 2011, 47, 93-106. [CrossRef]

63. Citarella, M.M.; Hallo, J.C.; Fefer, J.P.; Brownlee, M.T.; Powell, R.B.; DUdley, K.D. Taking the plunge: Enhancing the visitor experience in waterfall-based state parks. J. Park Recreat. Adm. 2019, 37, 70-88. [CrossRef]

64. Cohen, J.M.; Civitello, D.J.; Brace, A.J.; Feichtinger, E.M.; Otrtega, C.N.; Richardson, J.C.; Sauer, E.L.; Liu, X.; Rohr, J.R. Spatial scale modulates the strength of ecological processes driving disease distributions. Proc. Natl. Acad. Sci. USA 2016, 113, E3359-E3364. [CrossRef]

65. Ballantyne, M.; Gudes, O.; Pickering, C.M. Recreational trails are an important cause of fragmentation in endangered urban forests: A case-study from Australia. Landsc. Urban Plan. 2014, 130, 112-124. [CrossRef]

66. Wilson, M.C.; Chen, X.Y.; Corlett, R.T.; Didham, R.K.; Ding, P.; Holt, R.D.; Holyoak, M.; Hu, G.; Hughes, A.C.; Jiang, L.; et al. Habitat fragmentation and biodiversity conservation: Key findings and future challenges. Landsc. Ecol. 2016, 31, 219-227. [CrossRef]

67. Larson, C.L.; Reed, S.E.; Merelender, A.M.; Crooks, K.R. A meta-analysis of recreation effects on vertebrate species richness and abundance. Conserv. Sci. Pract. 2019, 1, e93. [CrossRef]

68. Larson, C.L.; Reed, A.M.; Merenlender, A.M.; Crooks, K.R. Effects of recreation on animals revealed as widespread through a global systematic review. PLOS ONE 2016, 11, e0167259. [CrossRef] [PubMed]

69. Marion, J.L.; Wimpey, J. Assessing the influence of sustainable trail design and maintenance on soil loss. J. Environ. Manag. 2017, 189, 46-57. [CrossRef]

70. Arrendondo, J.R. Modeling Areal Measures of Campsite Impacts on the Appalachian National Scenic Trail, USA Using Airborne LiDAR and Field Collected Data. Ph.D. Thesis, Virginia Tech, Blacksburg, VA, USA, 2018.

71. Marion, J.L.; Arredondo, J.; Wimpey, J.; Meadema, F. Applying recreation ecology science to sustainably manage camping impacts: A classification of camping management strategies. Int. J. Wilderness 2018, $24,16$.

72. Peterson, B.A.; Brownlee, M.T.; Marion, J.L. Mapping the relationships between trail conditions and experiential elements of long-distance hiking. Landsc. Urban Plan. 2018, 180, 60-75. [CrossRef]

73. Meadema, F.; Marion, J.L.; Arredondo, J.; Wimpey, J. The influence of layout on Appalachian Trail soil loss, widening, and muddiness: Implications for sustainable trail design and management. J. Environ. Manag. 2020, 257, 109986. [CrossRef]

74. D'Antonio, A.; Monz, C.; Larson, N.; Rohman, A. An application of recreation resource assessment techniques to inform management action in an urban-proximate natural area. J. Outdoor Recreat. Tour. 2016, 14, $12-21$. [CrossRef]

75. Twardock, P.; Monz, C.; Smith, M.; Colt, S. Long-term changes in resource conditions on backcountry campsites in Prince William Sound, Alaska, USA. Northwest Sci. 2010, 84, 223-232. [CrossRef]

76. Cole, D.N.; Foti, P.; Brown, M. Twenty years of change on campsites in the backcountry of Grand Canyon National Park. Environ. Manag. 2008, 41, 959-970. [CrossRef] 
77. Newman, P.; Fristrup, K.; Trevino, K.; Lawson, S.; Taff, D.; Weinzimmer, D.; Archie, T. Protecting soundscapes in US National Parks: Lessons learned and tools developed. J. Acoust. Soc. Am. 2012, 131, 3381. [CrossRef]

78. Perry, E.; Xiao, X. The Transportation Recreation Opportunity Spectrum as a spatial and quantitative metric: Results of a preliminary investigation at Yellowstone National Park. Illuminare 2017, 15, 13-33.

79. Xiao, X.; Perry, E.; Manning, R.E.; Krymkowski, D.; Valliere, W.; Reigner, N. Effects of transportation on racial/ethnic diversity of National Park Visitors. Leis. Sci. 2017, 39, 126-143. [CrossRef]

80. McCurdy, L.; Winterbottom, K.; Mehta, S.; Roberts, J. Using nature and outdoor activity to improve children's health. Curr. Probl. Pediatric Adolesc. Health 2010, 5, 102-117. [CrossRef] [PubMed]

81. Sallis, J.F.; Floyd, M.F.; Rodriguez, D.A.; Saelens, B.E. Role of built environments in physical activity, obesity, and cardiovascular disease. Circulation 2012, 125, 729-737. [CrossRef]

82. Thomsen, J.M.; Powell, R.B.; Monz, C. A systematic review of the physical and mental health benefits of wildland recreation. J. Park Recreat. Assoc. 2018, 36, 123-148. [CrossRef]

83. World Health Organization. Mental Health: Strengthening Our Response. Available online: https: //www.who.int/news-room/fact-sheets/detail/mental-health-strengthening-our-response (accessed on 30 July 2020).

84. Millennium Ecosystem Assessment. Ecosystems and Human Well Being: A Framework for Assessment; Island Press: Washington, DC, USA, 2003.

85. Bertram, C.; Rehdanz, K. The role of urban green space and human well-being. Ecol. Econ. 2015, 120, $139-152$. [CrossRef]

86. Pietila, M.; Nuvonen, M.; Borodulin, K.; Korpela, K.; Sievanen, T.; Tyrvainen, L. Relationships between exposure to urban green spaces, physical activity and self-rated health. J. Outdoor Recreat. Tour. 2015, 10, 44-54. [CrossRef]

87. Romagosa, F.; Eagles, P.; Lemieux, J. From the inside out to the outside in: Exploring the role of parks and protected areas as providers of human health and well-being. J. Outdoor Recreat. Tour. 2015, 10, 70-77. [CrossRef]

88. Lee, J.; Park, B.J.; Tsunetsugu, Y.; Kagawa, T.; Miyazaki, Y. Restorative effects of viewing real forest landscapes, based on a comparison with urban landscapes. Scand. J. For. Res. 2009, 24, 227-234. [CrossRef]

89. Brown, D.K.; Barton, J.L.; Gladwell, V.F. Viewing nature scenes positively affects recovery of autonomic function following-acute-mental stress. Environ. Sci. Technol. 2013, 47, 5562-5569. [CrossRef] [PubMed]

90. Abbott, L.A.; Taff, B.D.; Newman, P.; Benfield, J.A.; Mowen, A.J. Influence of natural sounds on restoration. J. Park Recreat. Adm. 2016, 34, 5-15.

91. Harmon, D.; Putney, A. The Full Value of Parks: From Economics to the Intangible; Rowman \& Littlefield Publishers: New York, NY, USA, 2003.

92. McBride, D.L.; Korell, G. Wilderness therapy for abused women. Can. J. Couns. 2005, 39, 3-14.

93. Bahaeloo-Horeh, S.; Assari, S. Students experience self-esteem improvement during mountaineering. Wilderness Environ. Med. 2008, 19, 181-185. [CrossRef]

94. Rice, W.L.; Taff, B.D.; Miller, Z.D.; Newman, P.; Zipp, K.Y.; Pan, B.; Newton, J.N.; D'Antonio, A. Connecting motivations to outcomes: A study of park visitors' outcome attainment. J. Outdoor Recreat. Tour. 2020, 29, 100272. [CrossRef]

95. Manning, R.E. Frameworks for defining and managing the wilderness experience. In Proceedings of the Wilderness Visitor Experiences: Progress in Research and Management, Missoula, MT, USA, 4-7 April 2011.

96. Parker, S. Leisure in the life cycle. In Land and Leisure; Van Doren, S., Priddle, G.B., Lewis, J.E., Eds.; Routledge: London, UK, 2019; pp. 25-35.

97. Roper, S. Camp 4: Recollections of a Yosemite Rockclimber; The Mountaineers: Seattle, WA, USA, 1994.

98. Leroux, S.J.; Krawchuk, M.A.; Schmiegelow, F.; Cumming, S.G.; Lisgo, K.; Anderson, L.G.; Petkova, M. Global protected areas and IUCN designations: Do the categories match the conditions? Biol. Conserv. 2010, 143, 609-616. [CrossRef]

99. Reigner, N.; Lawson, S.; Meldrum, B.; Pettebone, D.; Newman, P.; Gibson, A.; Kiser, B. Adaptive management of visitor use on Half Dome, an example of effectiveness. J. Park Recreat. Adm. 2012, 30, 64-78.

100. Taff, D.; Newman, P.; Pettebone, D.; White, D.D.; Lawson, S.R.; Monz, C.; Vagias, W.M. Dimensions of alternative transportation experience in Yosemite and Rocky Mountain National Parks. J. Transp. Geogr. 2013, 30, 37-46. [CrossRef] 
101. Atkinson, K.J. The Alaska National Interest Lands Conservation Act: Striking the balance in favor of customary and traditional subsistence uses by Alaska Natives. Nat. Resour. J. 1987, 27, 421.

102. Blodgett, P. Defining Uncle Sam's Playgrounds: Railroad Advertising and the National Parks, $1917-1941$. Hist. Geogr. 2007, 35, 80-113.

103. Darrien, M.; Stokowski, P. Discourses of place: Environmental interpretation about Vermont forests. Environ. Commun. 2016, 11, 276-287. [CrossRef]

104. Xiao, X.; Seekamp, E.; Van Der Berg, M.P.; Eaton, M.; Fatoric, S.; McCreary, A. Optimizing historic preservation under climate change: Decision support for cultural resource adaptation planning in national parks. Land Use Policy 2019, 83, 379-389. [CrossRef]

105. Byrne, J.P. Hallowed ground: The Gettysburg Battlefield in historic preservation law. Tulane Environ. Law J. 2009, 22, 203-269. [CrossRef]

106. Farrell, M.M.; Burton, J.F. From forgotten to national monument: Community archaeology at a World War II internment camp in Hawai 'i. Springer. In Transforming Heritage Practice in the 21st Century; Jameson, J.H., Musteata, S., Eds.; Springer Nature: Cham, Switzerland, 2019; pp. 283-301.

107. Laven, C.L.; Krymkowski, C.L.; Ventriss, C.L.; Manning, R.E.; Mitchell, N.J. From partnerships to networks: New approaches for measuring US National Heritage Area effectiveness. Eval. Rev. 2010, 34, 271-298. [CrossRef]

108. Kling, K.G.; Fredman, P.; Wall-Reinius, S. Trails for tourism and outdoor recreation: A systematic literature review. Tourism 2017, 65, 488-508.

109. Perry, E.; Krymkowski, C.L.; Manning, R.E. Brokers of relevance in National Park Service urban collaborative networks. Ecol. Soc. 2019, 24, 3. [CrossRef]

110. Hermes, J.; Van Erkel, D.; Burkhard, B.; Plieninger, T.; Fagerholm, N.; Von Haaren, C.; Albert, C. Assessment and valuation of recreational ecosystem services of landscapes. Ecosyst. Serv. 2018, 31, 289-295. [CrossRef]

111. Thomsen, J.M. An investigation of the critical events and influential factors to the evolution of the US Man and the Biosphere Program. Environ. Manag. 2018, 61, 545-562. [CrossRef]

112. National Park Service. NPS Theme Studies. Available online: https://www.nps.gov/subjects/ nationalhistoriclandmarks/full-list-of-theme-studies.htm (accessed on 30 July 2020).

113. Sziva, I.; Zoltay, R.A. How Attractive Can Cultural Landscapes Be for Generation Y? Almatourism. J. Tour. Cult. Territ. Dev. 2016, 7, 1-16.

114. Newman, J.; Cherney, A.; Head, B.W. Do policy makers use academic research? Reexamining the "two communities" theory of research utilization. Public Adm. Rev. 2016, 76, 24-32. [CrossRef]

115. Whiteside, M.; Tsey, K.; Cadet-James, Y. A theoretical empowerment framework for transdisciplinary team building. Aust. Soc. Work 2011, 64, 228-232. [CrossRef] 